\title{
RADIOISOTOPE TRANSPORT AND DEPOSITION IN FLOWING SODIUM
}

\author{
February 1969
}

\section{AEC RESEARCH \&}

DEVELOPMENT REPORT 


\section{LEGAL NOTICE}

This report was prepared as an account of Government sponsored work. Neither the United States, nor the Commission, nor any person acting on behalf of the Commission:

A. Makes any warranty or representation, expressed or implied, with respect to the accuracy, completeness, or usefulness of the information contained in this report, or that the use of any information, apparatus, method, or process disclosed in this repart may not infringe privately owned rights; or

B. Assumes any liabilities with respect to the use of, or for damages resulting from the use of any information, apparatus, method, or process disclosed in this report.

As used in the above, "person acting on behalf of the Commission" includes any employee or contractor of the Commission, or employee of such controctor, to the extent that such employee or contractor of the Commission, or employee of such contractor prepares, disseminates, or provides access to. any information pursuant to his employment or contract with the Commission, or his employment with such confractor.

\section{PACIFIC NORTHWEST LABORATORY \\ RICHLAND, WASHINGTON \\ operafed by}

BATTELLE MEMORIAL INSTITUTE

for the

UNITED STATES ATOMIC ENERGY COMMISSION UNDER CONTRACT AT(45-1)-1830 


\title{
RADIOISOTOPE TRANSPORT AND DEPOSITION \\ IN FLOWING SODIUM
}

\author{
By \\ W. F. Brehm, E. A. Kovacevich, and D. W. Shannon \\ FFTF Development Department \\ FFTF Project
}

February 1969

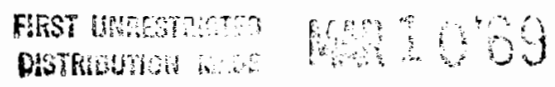

BATTELLE MEMORIAL INSTITUTE PACIFIC NORTHWEST LABORATORY RICHLAND, WASHINGTON 99352 
BNWL -969

Printed in the United States of America Available from

Clearinghouse for Federal Scientific and Technical Information National Bureau of Standards, U.S. Department of Commerce Springfield, Virginia 22151

Price: Printed Copy \$3.00; Microfiche $\$ 0.65$ 


\section{RADIOISOTOPE TRANSPORT AND DEPOSITION \\ IN FLOWING SODIUM \\ W. F. Brehm, E. A. Kovacevich, and D. W. Shannon}

\section{ABSTRACT}

Transport and deposition of radioisotopes released to flowing sodium from corrosion of irradiated stainless steel has been studied. Quantitative measurements of deposition can be made with sensitive counting techniques. The results of the study indicate that ${ }^{51} \mathrm{Cr}$ and ${ }^{60} \mathrm{Co}$ are transported primarily by isotopic exchange, and do not rapidly migrate to lower temperature regions of 100 p systems. However, ${ }^{54} \mathrm{Mn}$ is released in larger quantities to deposit throughout the test loops. Preferential deposition sites are (1) immediately downstream from the source, (2) at minimum temperature locations, and ( 3 ) in oxygen cold traps. These results indicate $54_{\mathrm{Mn}}$ is transported both by exchange and by solution-andprecipitation. Deposited ${ }^{54} \mathrm{Mn}$ migrated rapidly to the cold trap; deposited ${ }^{51} \mathrm{Cr}$ and ${ }^{60} \mathrm{Co}$ migrated slowly by exchange. 


\section{TABLE OF CONTENTS}

\begin{tabular}{|c|c|c|c|c|c|c|c|c|c|c|c|c|c|c|c|c|c|c|}
\hline L I S T & OF & FIGURE & & & . & . & . & • & & · & & . & . & . & • & . & . & vi \\
\hline LIST & OF & TABLES & & & . & . & . & . & & . & & . & . & . & . & . & . & $v i$ \\
\hline INTRO & ODUC & TION & . & & . & . & . & . & & . & & . & . & . & & . & . & 1 \\
\hline SUMMA & $A R Y$ & . & . & & . & . & . & . & & . & & . & . & . & & . & . & 3 \\
\hline DISCL & JS S I & & . & & . & . & . & • & & . & & . & . & . & & . & . & 5 \\
\hline & Exp & erimer & nta. & & Pro & ceed & ing & $s$. & & . & & . & . & . & . & . & . & 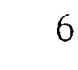 \\
\hline & Res & ults & . & & . & . & . & . & & . & & . & . & . & . & . & - & 10 \\
\hline & & $\operatorname{Effe}$ & ect & of & f V & le $10 c$ & ity & on & & $\operatorname{epc}$ & osit & tion & . & . & $\cdot$ & . & & 10 \\
\hline & & Effe & & of & f $T$ & Tempe & erat & ure & & and & Del & 1 ta- & $-T$ & $(\Delta \mathrm{T})$ & $\cdot$ & . & $\cdot$ & 13 \\
\hline & & Acti & ivi & & $\mathrm{Mi}$ & grat & ion & . & & . & & . & . & . & • & . & - & 13 \\
\hline & Con & clusio & ons & & . & . & . & . & & . & & . & . & . & & . & & 17 \\
\hline & Fut & ure Wo & ork & & . & . & . & . & & . & & . & . & . & $\cdot$ & . & - & 19 \\
\hline REFER & RENC & & . & & . & . & . & . & & . & & . & . & . & & . & & 20 \\
\hline DISTR & R I BU' & TION & . & & . & . & . & . & & . & & . & . & . & & . & . & 21 \\
\hline
\end{tabular}




\section{LIST OF FI GURES}

1 Schematic Diagram of Radioisotope Transport Loop 7

2 Schematic Diagram of Thermal Convection Loop 8

3 Counting Rate in Original Radioisotope Loop Run

4

Counting Rate of ${ }^{54} \mathrm{Mn}$ in Velocity Section

5 Comparison of Activity in Loops 4 and 5

Comparison of Activity Distribution in TC Loop 1

Before and After Running Loop Without Source Tab

Migration of ${ }^{54} \mathrm{Mn}$ in Radioisotope Loop

\section{LIST OF TABLES}

1 Typical Specimen Inventories

2 Counting Rates at Selected Areas in Radioisotope Transport Loop as Function of Time 


\section{RADIOISOTOPE TRANSPORT AND DEPOSITION \\ IN FLOWING SODIUM}

W. F. Brehm, E. A. Kovacevich, and D. W. Shannon

\section{INTRODUCTION}

The possibility of high radiation levels arising from transport and deposition of irradiated fue 1 cladding materials in FFTF primary system piping has been shown. $(1,2)$ we are investigating the effect of various reactor operating variables on the transport of irradiated stainless steel species through flowing sodium test loops. Our results are of value, not only to FFTF, but to any reactor system where the primary coolant circulates through a heat exchanger system.

This is the first in a series of reports describing our results. The work described herein was presented at the International Conference on Sodium Technology and Large Fast Reactor Design, held at Argonne National Laboratory, November 1968 . 

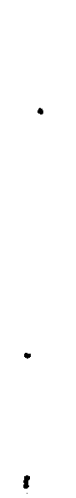

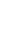




\section{SUMMARY}

Transport and deposition of radioisotopes released to flowing sodium from corrosion of irradiated stainless stee 1 has been studied. Quantitative measurements of deposition can be made with sensitive counting techniques. The results of the study indicate that ${ }^{51_{C r}}$ and ${ }^{60} \mathrm{Co}$ are transported primarily by isotopic exchange, and do not rapidly migrate to lower temperature regions of 100 p systems. However, ${ }^{54} \mathrm{Mn}$ is released in larger quantities to deposit throughout the test 1oops. Preferential deposition sites are (1) immediately downstream from the source, (2) at minimum temperature locations, and ( 3 ) in oxygen cold traps. These results indicate ${ }^{54} \mathrm{Mn}$ is transported both by exchange and by solutionand-precipitation. Deposited ${ }^{54} \mathrm{Mn}$ migrated rapidly to the cold trap; deposited ${ }^{5}{ }^{\mathrm{Cr}}$ and ${ }^{60} \mathrm{Co}$ migrated slowly by exchange.

The rapid transport of large amounts of ${ }^{54} \mathrm{Mn}$ to low temperature locations can create serious problems for reactor maintenance. Work is continuing to better define the factors which affect this deposition, and to develop methods for trapping radioisotopes in preselected, shielded, lowmaintenance locations. 
.

. 
BNWL- 969

\section{DISCUSSION}

In a sodium cooled fast reactor such as the FFTF, material will be lost from the stainless steel fuel cladding by the corrosive action of the flowing sodium coolant. Under ultimate operating conditions $\left(1200^{\circ} \mathrm{F}\right.$ bulk coolant temperature, $25 \mathrm{ft} / \mathrm{sec}$ sodium velocity, $10 \mathrm{ppm}$ oxygen in sodium) the rate of metal loss is approximately 0.0005 in. $(0.0013 \mathrm{~cm})$ per year. $(3,4)$ For 300 series stainless stee 1 at $1200^{\circ} \mathrm{F}$, this rate of metal loss is acceptable from cladding integrity considerations. More detailed information on all factors affecting metal loss rate is available. $(4,5,6)$

However, the material removed from the core will contain large amounts of radioisotopes produced from irradiation of the cladding. A typical inventory is the following: (1)

$$
\begin{aligned}
& { }^{51} \mathrm{Cr}, 27.8 \text { day half Iife }-2 \mathrm{Ci} / \mathrm{cm}^{3} \\
& { }^{58} \mathrm{Co}, 71 \text { day half } 1 \text { ife }-31 \mathrm{Ci} / \mathrm{cm}^{3} \\
& { }^{60} \mathrm{Co}, 1913 \text { day half } 1 \text { ife }-2 \mathrm{Ci} / \mathrm{cm}^{3} \\
& { }^{54} \mathrm{Mn}, 313 \text { day half } 1 \text { ife }-10 \mathrm{Ci} / \mathrm{cm}^{3}
\end{aligned}
$$

A study based on typical FFTF operation under the conditions described above has shown that about $1100 \mathrm{~cm}^{3}$ of material will be lost from the core and transported to other parts of the heat removal circuit in one year's operation. The isotope inventory will be approximate $1 \mathrm{y} 10,000 \mathrm{Ci}$, and the radiation level near heat removal system components may exceed $100 \mathrm{R} / \mathrm{hr}$ depending upon deposition conditions. Previous studies of transport and deposition of irradiated stainless steel in flowing sodium have shown that activity transport is not necessarily coincident with gross mass transport, but these data are very meager. $(7,8)$

Our experimental objective is to study the effect of various reactor operating variables such as temperature, 
system temperature gradient $(\Delta \mathrm{T})$, velocity, flow perturbations, and impurity level on the transport and deposition of these isotopes in test loops. The ultimate aim of the program is to identify the mechanisms of transport and deposition, and to make a quantitative model to predict deposition behavior in a reactor system. A necessary byproduct of this study will be development of methods to control or trap the isotopes in a shielded preselected location(s).

\section{EXPERIMENTAL PROCEEDINGS}

Two types of sodium loops are used: a pumped loop called the Radioisotope Transport Loop (RTL) and sma11 thermal convection (TC) loops. The RTL, constructed of 304 stainless steel, has a 2 gal/min capacity in the primary flow circuit. The primary contains a $40 \mathrm{~kW}$ direct resistance heater, a shielded specimen loading port, an isothermal velocity change section in the hot $1 \mathrm{eg}$, and an airblast heat exchanger. An $0.2 \mathrm{gal} / \mathrm{min}$ secondary circuit contains cold trap, plugging meter, and sample removal lines. A schematic of the RTL is shown in Figure 1 . The sodium velocity in the primary varies from $0.5 \mathrm{ft} / \mathrm{sec}$ in the heat exchanger to $40 \mathrm{ft} / \mathrm{sec}$ at the irradiated specimen location. The thermal convection loops are also made of 304 stainless steel; 15 in. high and 8 in. wide. Heat is supplied with a clamshell furnace and trace heating. An irradiated specimen is hung from a wire fastened to the loop cap. Typical velocity estimates are 0.2 to 0.8 $\mathrm{ft} / \mathrm{sec}$. A schematic TC loop is shown in Figure 2 .

Various irradiated stainless steel specimens are used. They fall into two categories: material irradiated in a thermal flux containing ${ }^{51} \mathrm{Cr},{ }^{60} \mathrm{Co}$, and ${ }^{59} \mathrm{Fe}$, and stock from EBR-II (fast flux) containing ${ }^{54} \mathrm{Mn}$ and small amounts of ${ }^{58}$ Co. Typical specimen inventories are given in Table 1 . 


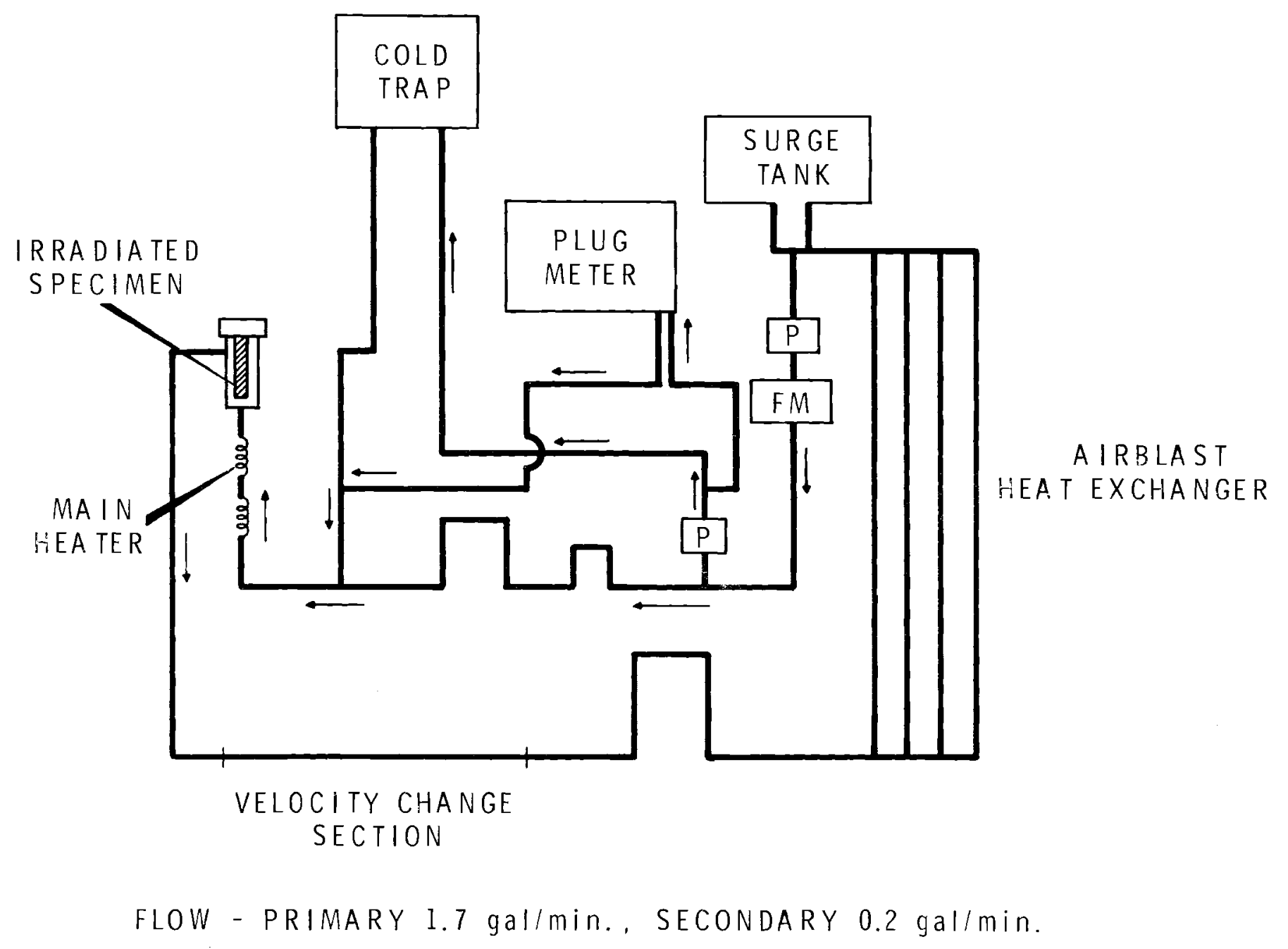

HIGURE 1. Schematic Diagram of Radioisotope Transport Loop 


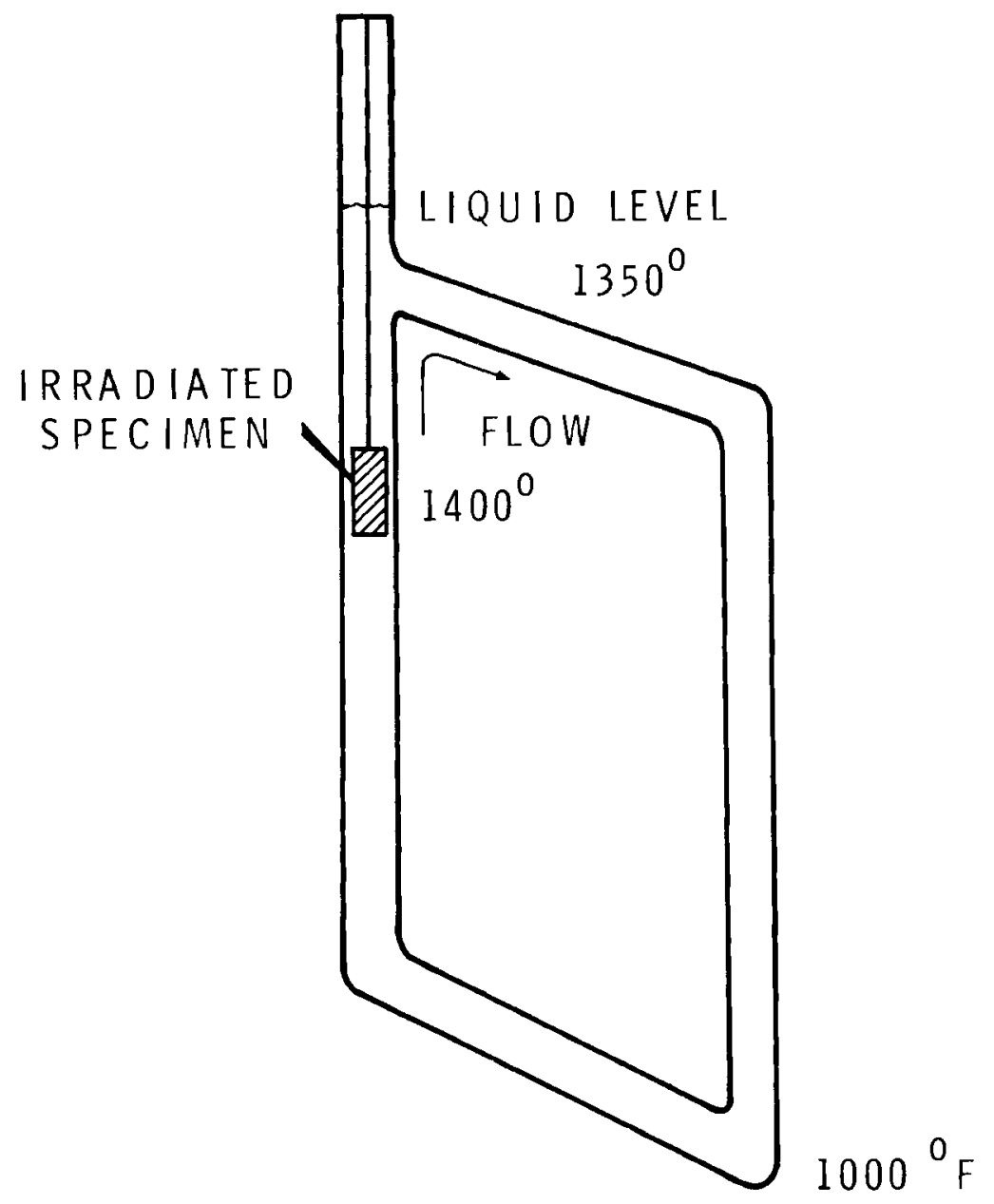

$V^{9 / 5}=\left(\frac{g \beta}{0.092}\right)\left(\frac{\rho_{0}}{\mu_{0}}\right)^{1 / 5} D^{6 / 5} \frac{h}{L} \Delta T$

FROM L.F. EPSTEIN, CORROSION BY LIQUID METALS, PROC. INTERN. CONF. PEACEFUL USES OF ATOMIC ENERGY. 1956, VOL 9, P 311.

$$
\begin{aligned}
& h=15 \mathrm{in} . \\
& L=4.5 \mathrm{in.} \\
& D=0.43 \mathrm{in.} \\
& V=0.2 \text { T0 } 0.8 \mathrm{ft} / \mathrm{sec} \\
& \operatorname{Re}=\frac{D_{V} \rho_{0}}{\mu_{0}}=1500 \text { T0 } 8000
\end{aligned}
$$

FIGURE 2. Schematic Diagram of Thermal Convection Loop 
TABLE 1. Tupical Specimen Inventories and Half-Lives

$$
\begin{aligned}
& { }^{58} \mathrm{Co}, 71 \text { days, } 60 \mathrm{\mu Ci} / \mathrm{g} \\
& { }^{60} \mathrm{Co}, 1913 \text { days, } 560 \mathrm{HC} / \mathrm{g} \\
& { }^{51} \mathrm{Cr}, 278 \mathrm{days}, 2 \times 10^{5} \mathrm{\mu Ci} / \mathrm{g} \\
& { }^{59} \mathrm{Fe}, 45 \mathrm{days}, 3 \times 10^{4} \mathrm{Hi} / \mathrm{g} \\
& \mathrm{EBR}-\mathrm{II} \text { stock, out of reactor } 18 \text { months } \\
& { }^{58} \mathrm{Co}, 1000 \mathrm{\mu Ci} / \mathrm{g} \\
& { }^{60} \mathrm{Co}, 600 \mathrm{\mu Ci} / \mathrm{g} \\
& { }^{54} \mathrm{Mn}, 313 \mathrm{days}, 3 \times 10^{4} \mathrm{\mu Ci} / \mathrm{g}
\end{aligned}
$$

The use of radioactive specimens and the counting techniques give us a very powerful tool for observing migration of various elements in a test loop. The loops are scanned either in place with a portable lead-shielded NaI crystal, or sections are cut from the loops and counted in a shielded well with a NaI crystal or a $20 \mathrm{~cm}^{3}$ lithium-drifted germanium diode. Counts are analyzed in a 4096 channel analyzer. Calibration by the first (in-place) method has been achieved by counting radioactive solutions of known inventory in pipes of the same size as loop piping. Thus absolute quantities of radioactive material can be measured in many instances. Further advantages of the in situ method are these: counting can be done quickly and without elaborate preparations, the method is nondestructive, and loop tests can quickly be resumed. Disadvantages include low sensitivity (about 1500 disintegrations/count), poor resolution ( $10 \mathrm{keV} / \mathrm{channel}$ ), and Bremstrahlung generated in the pipe interferes with low-energy gamma ray detection. Counting in the well eliminates these problems, especially when the diode is used, but it is more time consuming and requires either a tab specimen in the loop or a part of the loop which must then be replaced. Counting in the well is usually done to supplement and clarify the data from the more rapid in-place scanning. 
$\underline{\text { RESULTS }}$

The first tests were run in the RTL and TC loops with a thermal-irradiated specimen. The results were similar: ${ }^{51} \mathrm{Cr}$ and ${ }^{60}$ Co were released from the specimen but migrated only a short distance downstream, as shown in Figure 3 . Neither ${ }^{51} \mathrm{Cr}$ nor ${ }^{60}$ Co was found in the heat exchanger or cold trap of the RTL. The data of Figure 3 are not decay-corrected; the original Cr level was two orders of magnitude higher. This is an example of radioisotope transport by isotopic exchange. Analysis of loop sodium showed ${ }^{60} \mathrm{Co},{ }^{51} \mathrm{Cr}$, and traces of ${ }^{54} \mathrm{Mn}$, indicating higher ${ }^{54} \mathrm{Mn}$ solubility. No ${ }^{59} \mathrm{Fe}$ has ever been identified on loop piping even though substantial amounts of ${ }^{59} \mathrm{Fe}$ are present in the source tab. The first RTL run with an EBR-II irradiated specimen gave quite different results: the amount of manganese released was about 10 times the amount of chromium released in the other test, and ${ }^{54} \mathrm{Mn}$ was found all over the loop. High counting rates were obtained in the following regions immediately downstream of the specimen, in the crossover pipe from heat exchanger outlet to surge tank, and in the cold trap. This shows that some ${ }^{54} \mathrm{Mn}$ is transported by exchange, but the preferential deposition at lower temperature regions suggests transport also occurs by solution and precipitation, possibly assisted in the cold trap by chemical reaction with the $\mathrm{Na}_{2} \mathrm{O}$ to form $\mathrm{NaMnO}_{4}$. (9) Specimens showed weight losses that were in approximate agreement with weight losses previously reported. (2)

\section{Effect of Velocity on Deposition}

Deposition of ${ }^{54} \mathrm{Mn}$ in the velocity change section of the RTL varied as shown in Figure 4. Note that the abscissa of the graph is dpm/in. ${ }^{2}$. These measurements can be made with our calibrated counting technique. This part of the loop is isothermal at $1300^{\circ} \mathrm{F}$, so the deposition is taking place by exchange. The higher deposition rate at the higher velocity 


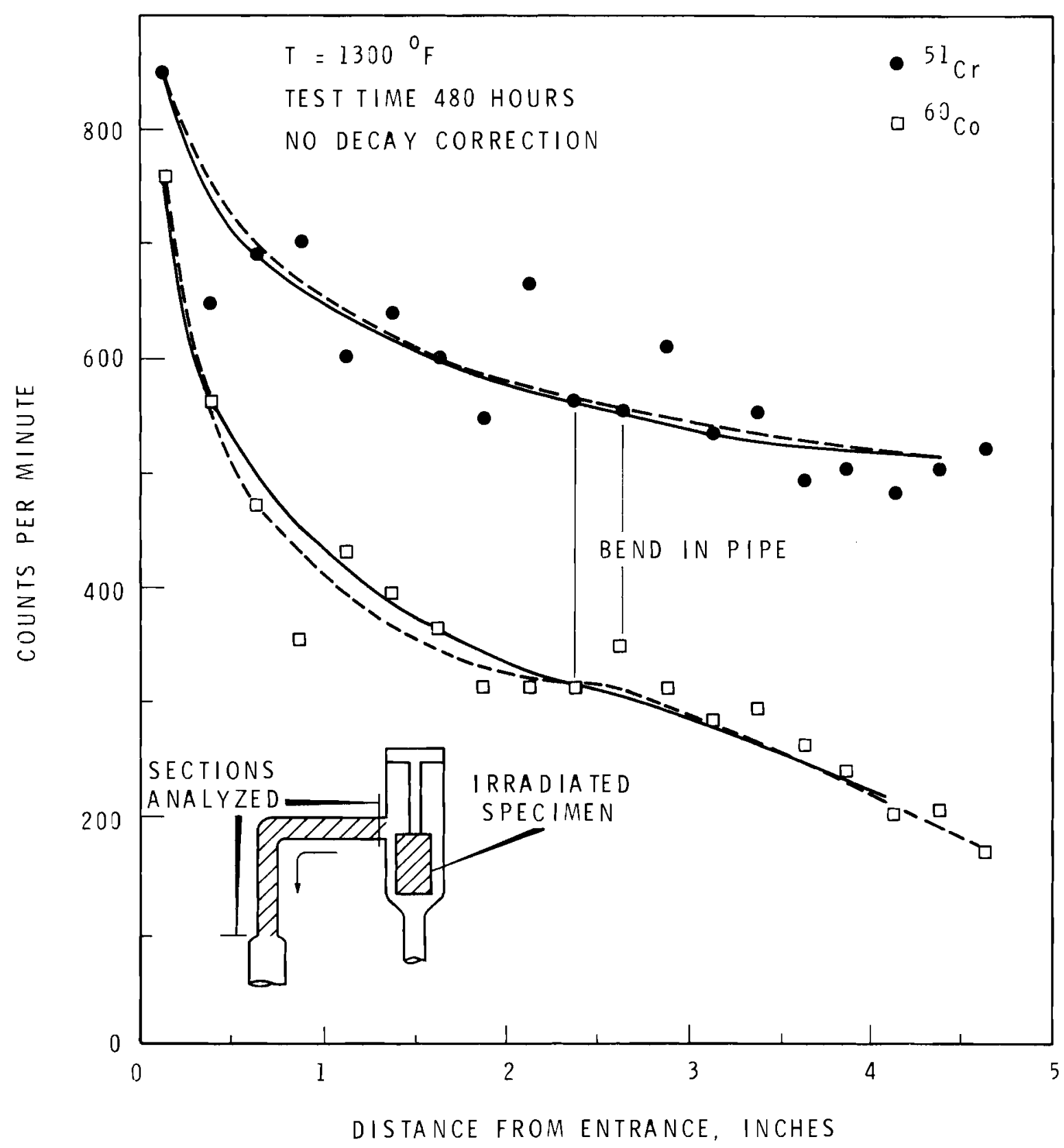

FIGURE 3. Counting Rate in Original Radioisotope Loop Run 

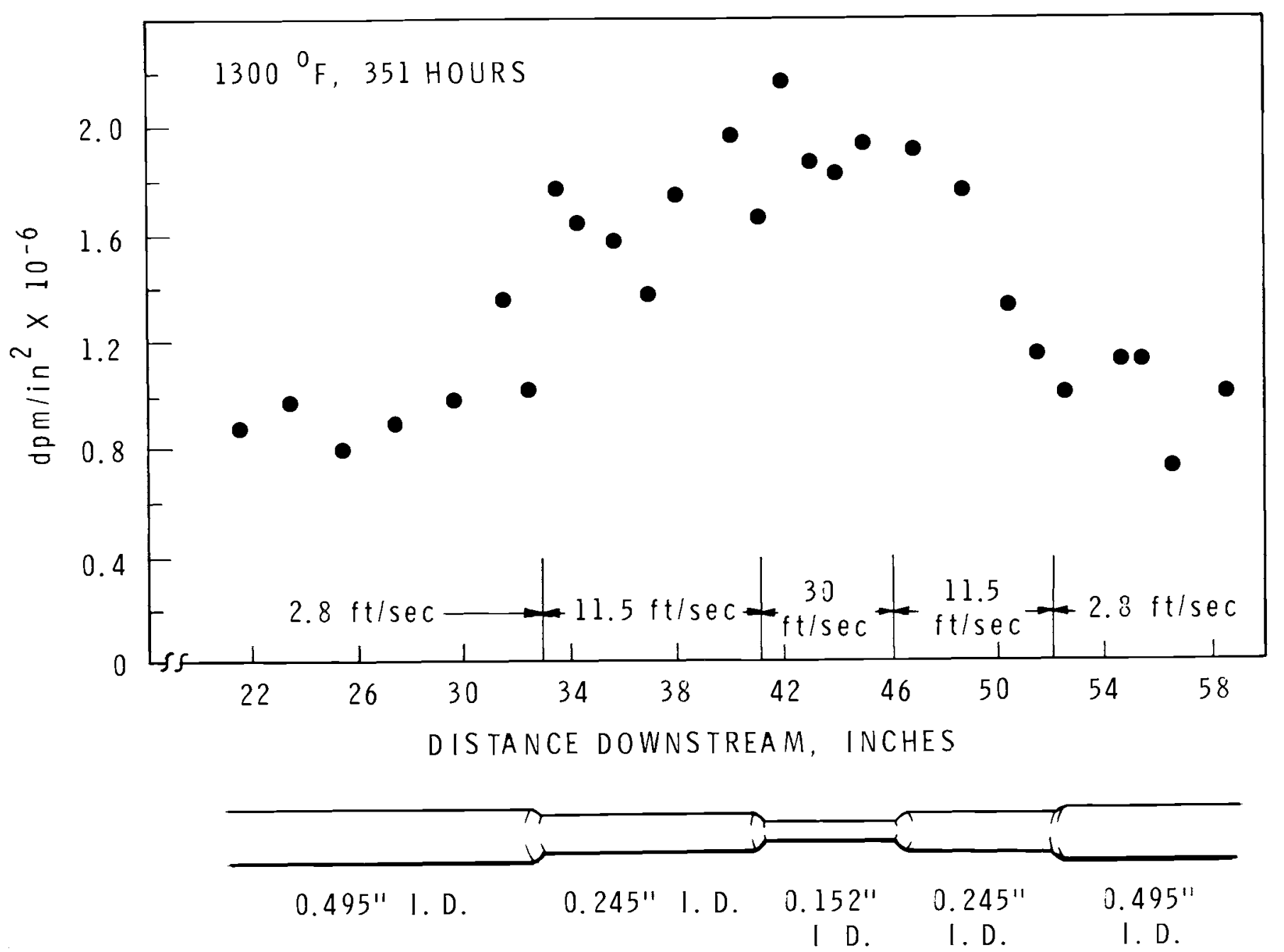

EIGURE 4. Counting Rate of ${ }^{54} \mathrm{Mn}$ in velocity section 
suggests the rate-limiting step for deposition is diffusion through a boundary layer which decreases in thickness with increasing velocity. Similar indicative results were obtained in the cold leg of the RTL. Cobalt-58 was not found.

Effect of Temperature and Delta-T $(\Delta T)$

Tests in thermal convection 1oops with ${ }^{54} \mathrm{Mn}$-bearing specimens gave the following indicative results. In the absence of large temperature gradients (1ess than $200^{\circ} \mathrm{F}$ difference between maximum and minimum temperatures) in a TC $100 \mathrm{p},{ }^{54} \mathrm{Mn}$ is also transported chiefly by isotopic exchange. However, at a larger $\Delta \mathrm{T}\left(400^{\circ} \mathrm{F}\right)$ the segregation of ${ }^{54} \mathrm{Mn}$ to the cold side of the loop occurred (1400 ${ }^{\circ} \mathrm{F}$ specimen temperature and a $1000^{\circ} \mathrm{F}$ minimum temperature). Comparison of the two cases is shown in Figure 5. The ratio of counts at the minimum temperature location to counts at maximum temperature location in TCL Number 5 was 5.6; the ratio in another 10 op with $1230{ }^{\circ} \mathrm{F}$ maximum, $1050{ }^{\circ} \mathrm{F}$ minimum was 1.4. More than three times as much activity was released from the specimen at $1400^{\circ} \mathrm{F}$ as at $1230^{\circ} \mathrm{F}$. These results show that both specimen temperature and loop $\Delta \mathrm{T}$ affect the transport of ${ }^{54} \mathrm{Mn}$. Work is in progress to attempt to define the affect of each variable separate1y.

Activity Migration

One of the most interesting aspects of our work concerns the migration of deposited activity. When the irradiated specimen is removed from the loop and sodium flow is resumed, transport of the deposited radioactive material can be analyzed without the uncertainty as to whether the atoms in question migrated from a previous deposition site, or whether they were released from the source. Such measurements are difficult to make with nonradioactive material. 


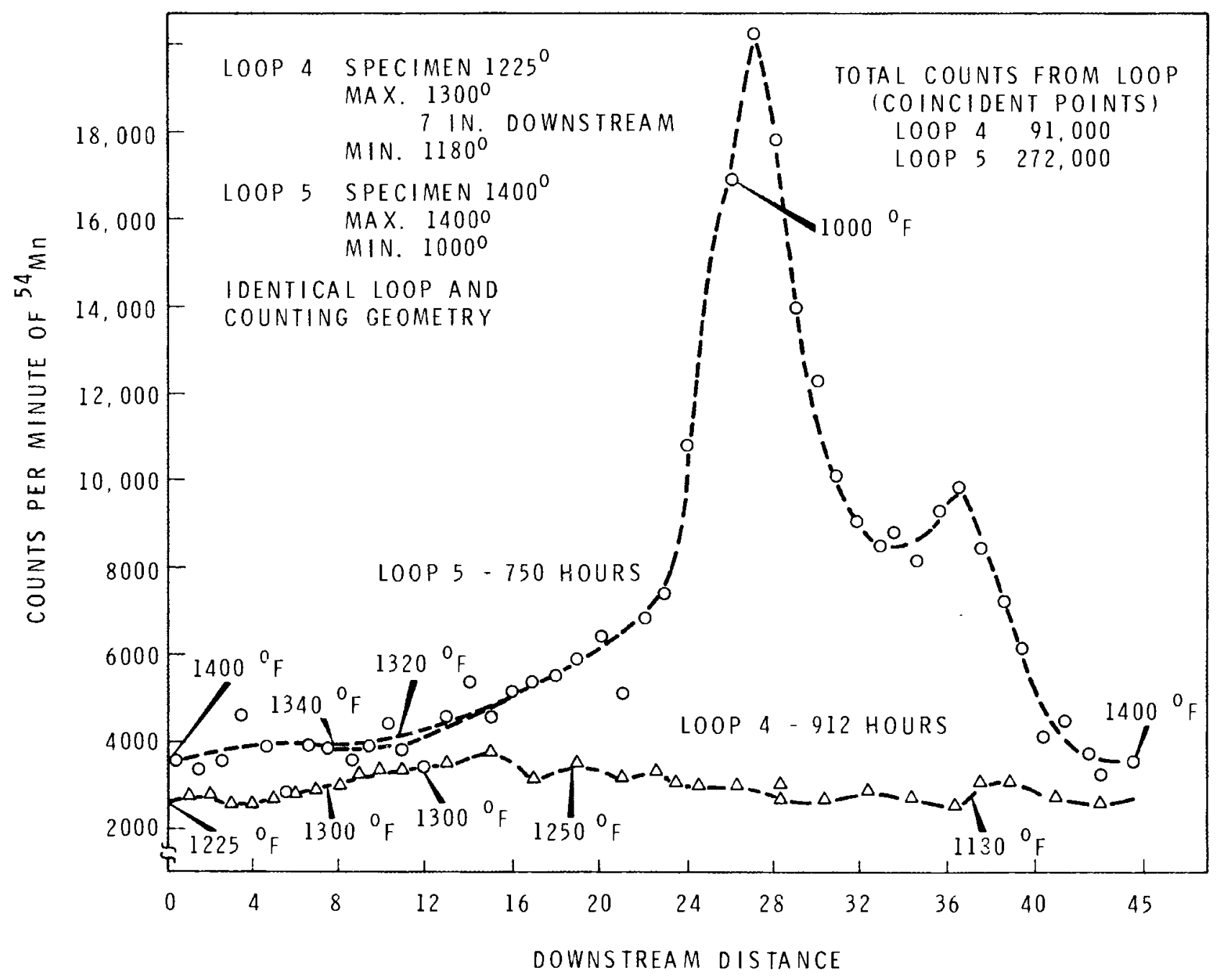

FIGURE 5. Comparison of Activity in Loops 4 and 5 
Limited information available shows that ${ }^{5} 1_{\mathrm{Cr}}$ migrates very slowly (in thermal convection loops) by isotopic exchange. Figure 6 shows the results of one of these tests. A similar test in which the loop was cut up and we11-counted showed a similar profile for ${ }^{60} \mathrm{Co}$. In this 1 atter test, small amounts of ${ }^{54} \mathrm{Mn}$ were found on the pipe walls. Since only trace amounts of ${ }^{54} \mathrm{Mn}$ are produced in thermal irradiations, this result shows both the sensitivity of the counting technique and the preferential solubility of manganese in sodium. Chromium has also been reported to have preferential (with respect to iron and cobalt) solubility in sodium, but chromium migration similar to that observed has also been reported. (10)

The migration of ${ }^{54} \mathrm{Mn}$ in the RTL for two more runs produced a steady decrease in ${ }^{54} \mathrm{Mn}$ activity throughout most of the primary system, and an increase in activity in the cold trap. These results are presented in Table 2 .

\section{TABLE2. Counting Rates at Selected Areas in Radioisotope ${ }_{54}$, Test conditions - (1) Irradiated specimen in place 351 hr; (2) Exposure 1 plus 416 hr without specimen, (3) Exposure 2 plus 384 hr additional.)}

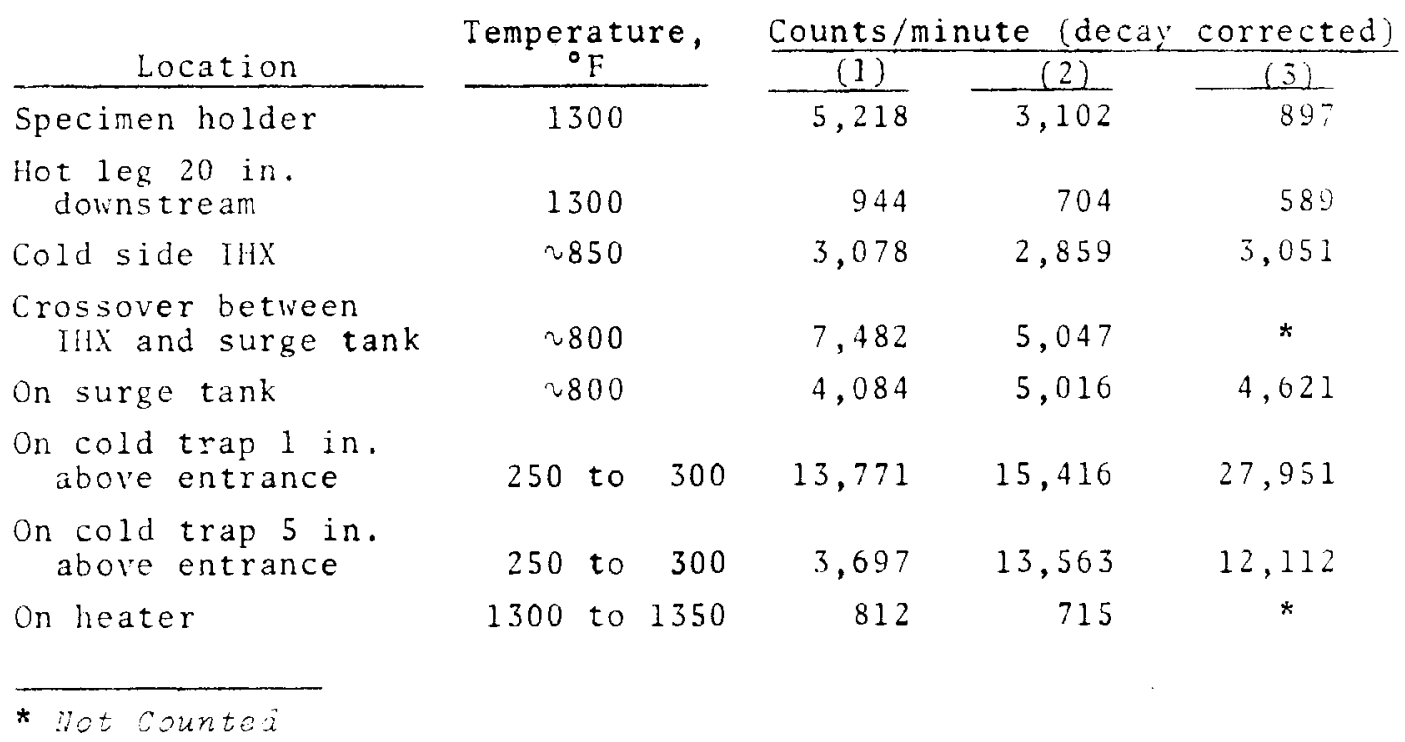




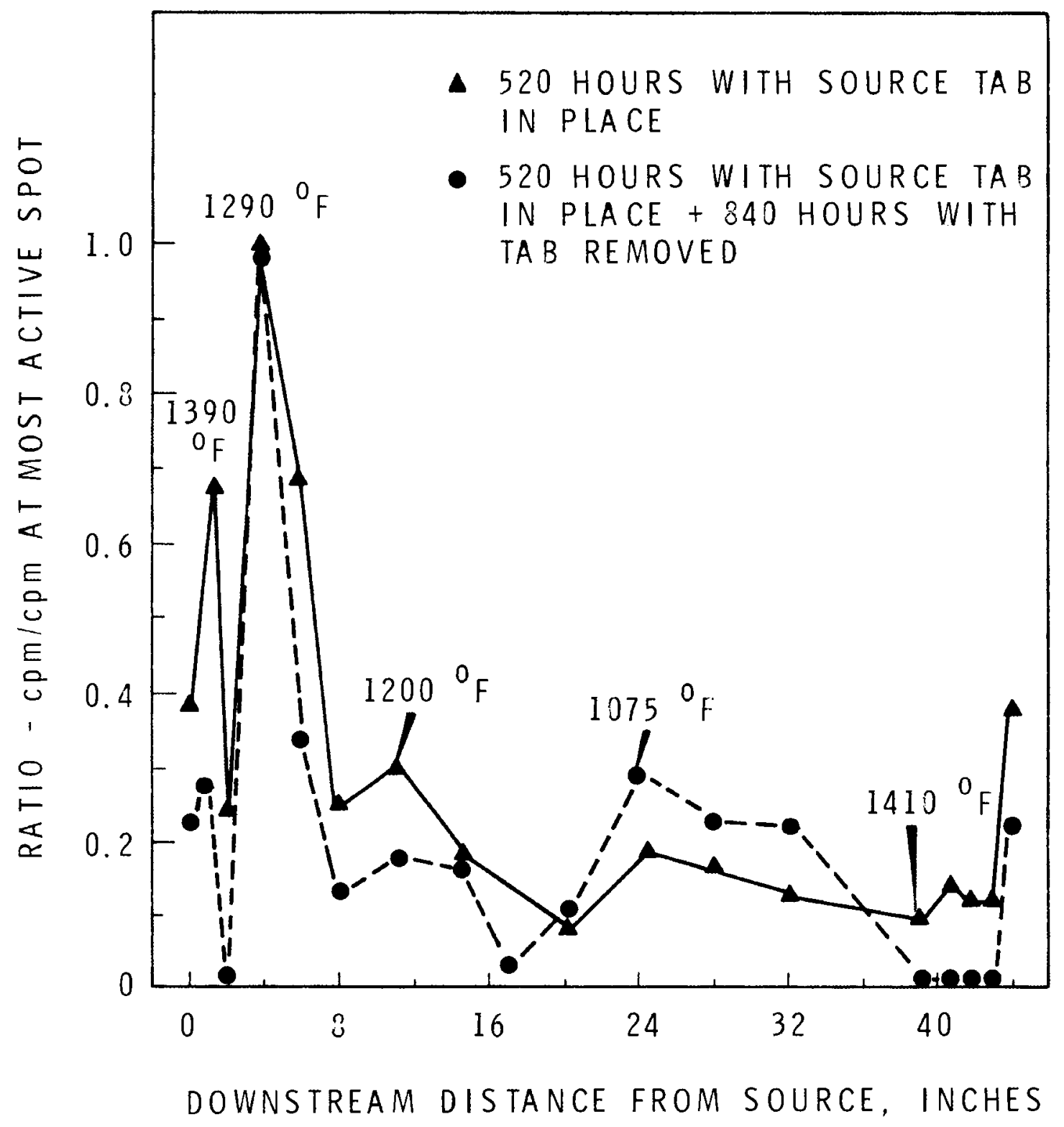

EIGURE 6. Comparison of Activity Distribution in TC Loop 1 Before and After Running Loop Without Source Tab. Active species - ${ }^{51} \mathrm{Cr}, 30$ min counts 
A graph of ${ }^{54} \mathrm{Mn}$ migration in the hot 1 eg is shown in Figure 7 . The peak near 31 in. in the restart data (open circles) is probably the result of some of the atoms migrating from their original deposition location near the source to that location by isotopic exchange. However, note that everywhere else there has been a decrease in activity.

Some of the deposited radioactive atoms diffuse into the pipe wall. Diffusion of ${ }^{51} \mathrm{Cr}$ and ${ }^{54} \mathrm{Mn}$ has been observed. The rate of penetration is roughly that which would be predicted by diffusion theory.

\section{CONCLUSIONS}

The obvious conclusions one can draw from this work are that different isotopes are transported in sodium loops by different processes, and each process is dependent on flow, temperature, and chemistry. Much more to the point, however, is a consideration of the implications the results of this work will have on reactor operation. The heat exchanger in the RTL has a radiation field of about $2 \mathrm{mR} / \mathrm{hr}$ from deposited ${ }^{54} \mathrm{Mn}$ (remember that it is not the major deposition site). The irradiated specimen lost about $15 \mathrm{mg}$ of material in one month. Predicted weight loss for one year in the FFTF core under ultimate operating conditions is $3 \mathrm{~cm}^{3} /$ day or about $8000 \mathrm{~g} /$ year. (6) This material will have a specific activity 100 times that used in our test. If one assumes that the FFTF heat transport system has 1000 times the surface area of the loop, and also assumes that deposition is proportional to surface area for constant temperature profiles, then a crude extrapolation $c$ an be made:

$\frac{8000 \mathrm{~g} \text { in FFTF }}{0.015 \mathrm{~g} \text { in } 100 \mathrm{p}} \times 100$ factor for specific activity $\times \frac{1}{1000}$ factor for area $=53,333$ factor increase. 


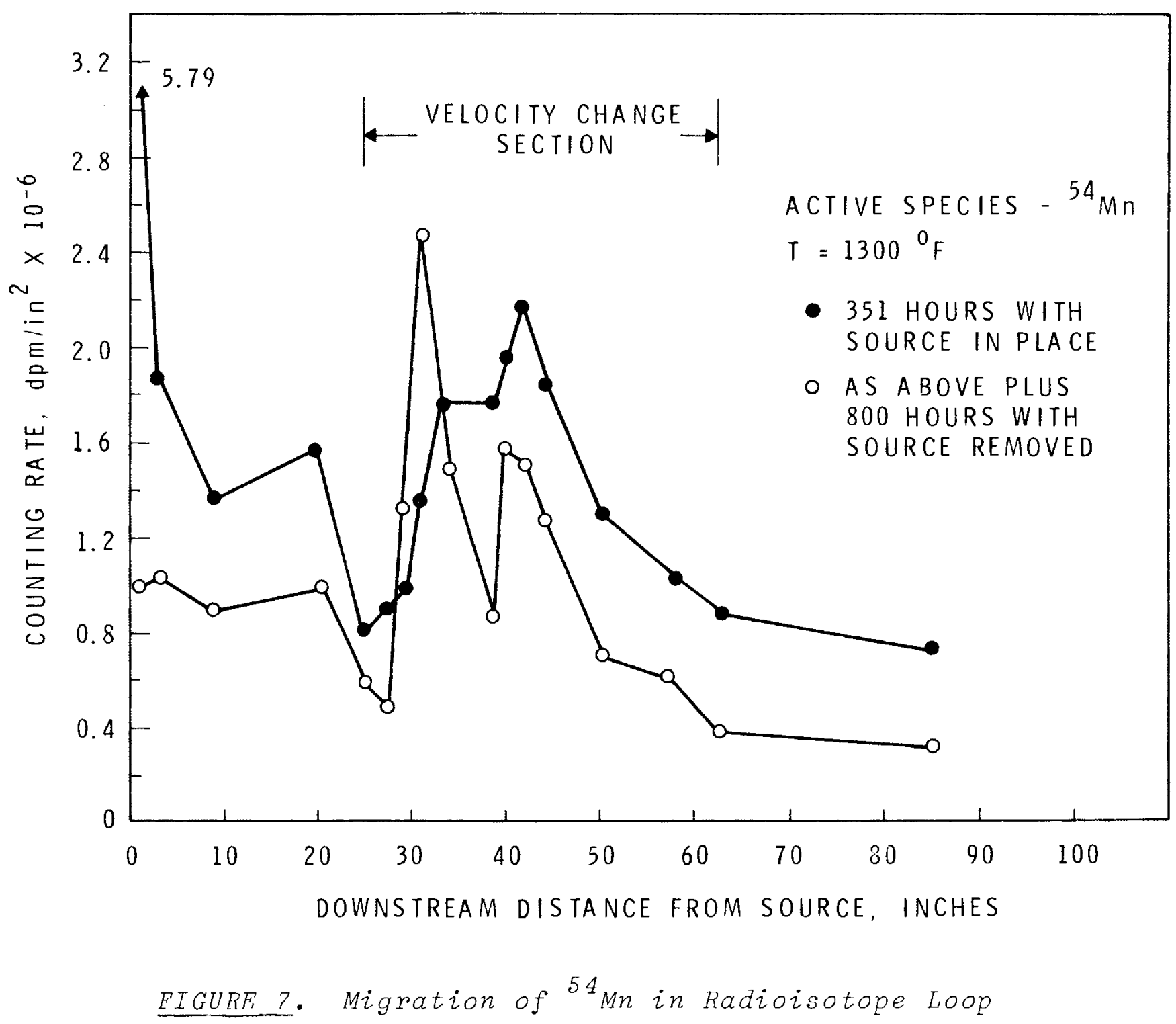

莣
1
6
6
6 
This factor increases the extrapolated radiation level to $106 \mathrm{R} / \mathrm{hr}$, completely intolerable for contact maintenance.

Taken in this light, one can see that either FFTF heat removal system must be designed for remote maintenance (core and probably closed loops) or transport and deposition mechanisms must be identified so that preferential deposition sites can be identified. An ideal situation would be to design the heat removal loops such that areas that may need maintenance would not be preferential deposition sites, and that deposition could be enhanced in low-maintenance areas that could be adequately shielded.

The results of our study show that ${ }^{54}$ Mn would be trapped just downstream of the heat exchanger and in the cold trap, especially if high velocity, high turbulence flow conditions are present there. Chromium-51 would probably be plated out on the top of the fuel pins just above the core, and may possibly have decayed away by the time the chromium atom is "exchanged" off the top of the fue 1 pin. Cobalt-58 and ${ }^{60} \mathrm{Co}$ should behave similarly to ${ }^{51} \mathrm{Cr}$, but not enough data are available to really tell.

FUTURE WORK

The future work on this study will involve redesign of the RTL and TC loops for insertion of more tab and ring specimens to take advantage of the strong points of both counting techniques. The RTL redesign will incorporate coplanar tubing for better detector positioning, and seriesflow heat exchanger and cold trap for better determination of (isotope concentration versus temperature) profiles. A high-cobalt stainless steel is being irradiated to introduce enough ${ }^{60}$ Co into the loops for easier detection. 
BNWL- 969

\section{REFERENCES}

1. D. W. Shannon. Fast Reactor Corrosion and Chemistry, Interim Technical Progress Report No. 1, BNWL-483. Battelle-Northwest, Richland, Washington, 1967.

2. W. F. Brehm. Radioactive Mass Transport in FFTF Primary Piping, BNWL-808. Battelle-Northwest, Richland, Washington, 1968 .

3. P. T. Nettley et al. "Problems in the Selection and Utilization of Materials in Sodium Cooled Fast Reactors," Fast Breeder Reactors. Pergamon Press, oxford, 1966.

4. M. C. Rowland et al. Sodium Mass Transfer XV. Behavior of Selected Steels Exposed in Flowing Sodium Test Loops, GEAP-4831. General Electric Company, San Jose, Calif., 1965 .

5. E. G. Brush. Sodium Mass Transfer XVI. The Selective Corrosion Component of Steel Exposed to Flowing Sodium, GEAP-4832. General Electric Company, San Jose, Calif., 1965 .

6. Alkali Metal Coolants. Proceedings of Symposium in Vienna, November-December 1966. International Atomic Energy Agency, Vienna, 1967.

7. R. W. Lockhart. Sodium Mass Transfer II, Screening Test Data and Analysis. Vol. I Mass Transfer Results, GEAP-3726. General Electric Company, San Jose, Calif., 1962 .

8. F. G. Haag. "Material Transport in Sodium Systems," Chem. Eng. Progr., Symp. Ser., vol. 20, no. 53, pp 43-50. 1957 .

9. Fast Flux Test Facility Quarterly Progress Report for April-June 1968, BNWL-880. Battelle-Northwest, Richiand, Washington, october 1968.

10. G. F. Wozadio, F. A. Comprelli, and R. S. Young. Mass Transfer Studies and Related Metallurgical Effects for Austenitic Stainless Steel in High-Temperature Pumped Sodium Systems, Paper presented at AEC Corrosion Symposium, Coiumbus, ohio, May 1968. 
BNWL - 969

\section{DISTRIBUTION}

No. of

Copies

\section{OFFS ITE}

AEC Chicago Patent Group

G. H. Lee

AEC Division of Reactor Development and Technology

$M$ Shaw, Director, RDT

Asst Dir for Nuclear Safety

Analysis \& Evaluation Br, RDT:NS

Environmental \& Sanitary Engrg

$\mathrm{Br}, \mathrm{RDT}: \mathrm{NS}$

Research \& Development Br, RDT:NS

Asst Dir for Plant Engrg, RDT

Applications \& Facilities Br, RDT:PE

Components $\mathrm{Br}, \mathrm{RDT}: \mathrm{PE}$

Instrumentation $\&$ Control $\mathrm{Br}, \mathrm{RDT}: \mathrm{PE}$

Liquid Metal Systems Br, RDT:PE

Asst Dir for Program Analys is, RDT

Asst Dir for Project Mgmt, RDT

Liquid Metals Projects Br, RDT:PM

FFTF Project Manager, RDT:PM (3)

Asst Dir for Reactor Engrg

Control Mechanisms Br, RDT:RE

Core Design Br, RDT : RE (2)

Fuel Fabrication $\mathrm{Br}$, RDT:RE

Fuel Handling $\mathrm{Br}$, RDT : RE

Reactor Vessels Br, RDT:RE

Asst Dir for Reactor Tech

Coolant Chemistry $\mathrm{Br}$, RDT

Fuel Recycle Br, RDT

Fuels \& Materials Br, RDT: RT

Reactor Physics Br, RDT:RT

Special Technology Br, RDT:RT

Asst Dir for Engrg Standards, RDT

258 AEC Division of Technical Information Extension

1 AEC Idaho Operations office

Nuclear Technology Division

C. W. Bills, Director

1 AEC San Francisco Operations office Director, Reactor Division 
BNWL -969

No. of

Copies

$4 \quad$ AEC Site Representatives

Argonne National Laboratory

Atomics Internationa 1

Atomic Power Development Assoc.

General Electric Co.

2 Argonne National Laboratory

LMFBR Program office

1 Atomic Power Development Assoc.

Document Librarian

$7 \quad$ Atomics International

D. J. Cockeram (5)

Liquid Metal Information Center

J. J. Droher (2)

2 Babcock \& Wilcox Co.

Atomic Energy Division

S. H. Es leeck

G. B. Garton

5 Bechtel Corporation

J.J. Teachnor, Project Administrator, FFTF

1 BNW Representative

N.A. Hill (ZPR III)

1 Combustion Engineering

1000 MWe Follow-On Study

W. P. Staker, Project Manager

5 General Electric Co.

Advanced Products Operation

Karl Cohen (3)

Bertram Wolfe

Nuclear Systems Programs

D. H. Ahmann

2 Gulf General Atomic Inc.

D. Coburn 


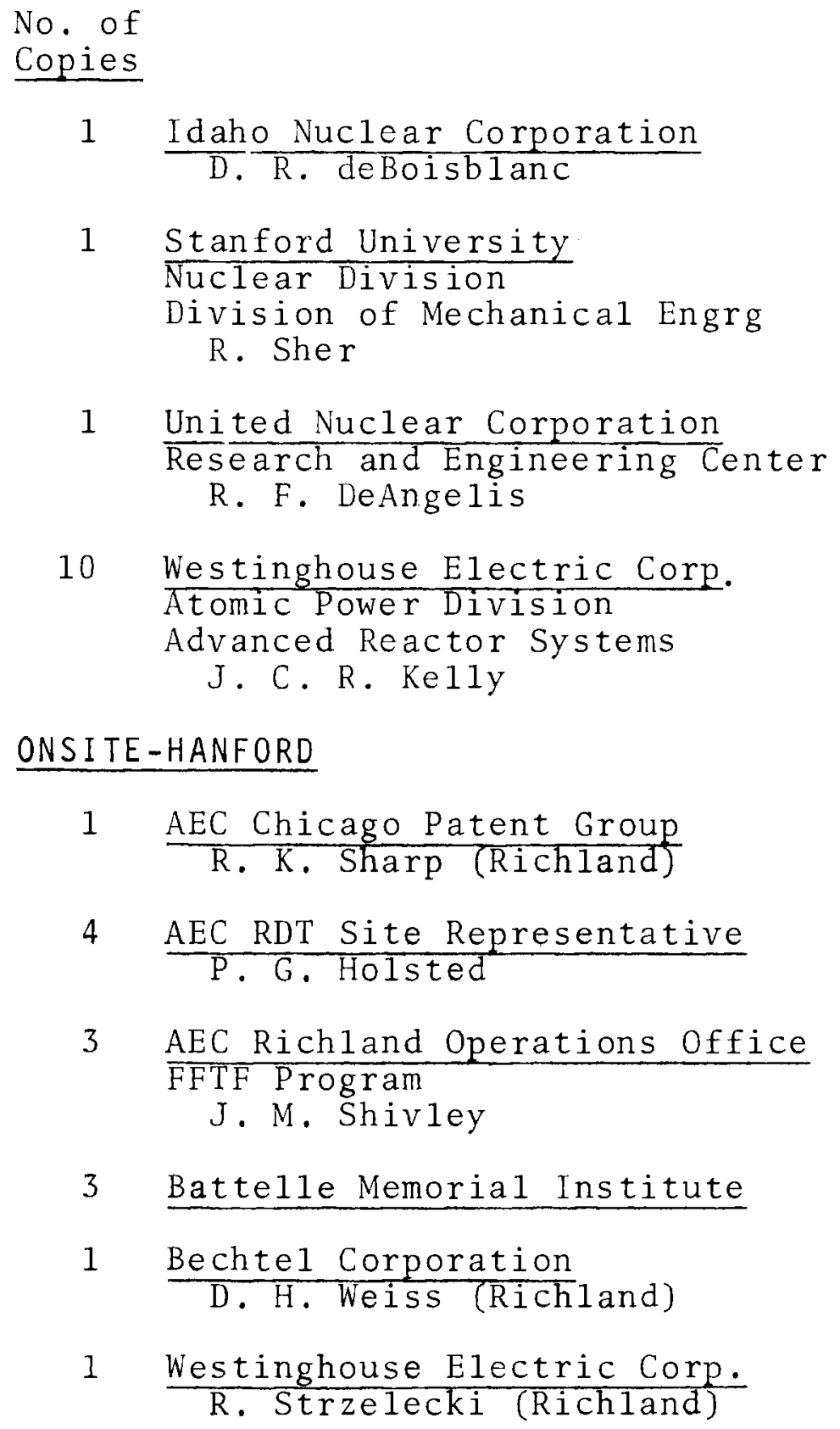

1 United Nuclear Corporation Research and Engineering Center R. F. DeAngelis

10 Westinghouse Electric Corp. Atomic Power Division Advanced Reactor Systems J. C. R. Ke11y

\section{ONSITE-HANFORD}

$1 \frac{\text { AEC Chicago Patent Group }}{\text { R. K. Sharp (Richland) }}$

4 AEC RDT Site Representative P. G. Holsted

3 AEC Richland Operations Office FFTF Program J. M. Shivley

3 Battelle Memorial Institute

1 Bechtel Corporation D. H. Weiss (Richland)

1 Westinghouse Electric Corp. R. Strzelecki (Richland) 
No. of

Copies

Q0 Battelle-Northwest

S. O. Arneson

D. H. Lester

E. R. Astley

C. W. Lindenmeier

T. Bauman

W. W. Little

A. L. Bement

R. A. Bennett

H. P. Maffei

G. R. Bloom

D. C. Boyd

W. F. Brehm (10)

D. Marinos

J. J. McCown

W. B. McDona $1 d$

W. L. Bunch

B. Mann

C. A. Munro

J. R. Carrell

R. E. Peterson

H. L. Pringle

W. E. Roake

T. T. Claudson

P. D. Cohn

D. L. Condotta

D. W. Shannon

R. J. Squires

G. M. Dalen

J. M. Davidson

D. D. Stepnewski

J. C. Tobin

R. R. Derusseau

M. A. Voge 1

R. L. Dillon

E. A. Evans

J. H. Westsik

J. F. Wett

L. M. Finch

L. A. Whinery

T. W. Withers

K. M. Harmon

R. E. Heineman

R. J . Hennig

P. L. Hofmann

B. M. Johnson

H. G. Johnson

R. N. Johnson

E. M. Johnston

P. L. Koehmstedt (2)

N. G. Wittenbrock

M. R. Wood

FFTF Files (10)

Technical Information

Files (5)

Technical Publications (2)

Legal (2)

E. A. Kovacevich (5) 